\title{
CEsifo \\ WORKING

Revealed Political Favoritism: Evidence from the Allocation of State Lottery Grants in

\section{Israel}

Momi Dahan, Itamar Yakir 


\section{Impressum:}

CESifo Working Papers

ISSN 2364-1428 (electronic version)

Publisher and distributor: Munich Society for the Promotion of Economic Research - CESifo

$\mathrm{GmbH}$

The international platform of Ludwigs-Maximilians University's Center for Economic Studies and the ifo Institute

Poschingerstr. 5, 81679 Munich, Germany

Telephone +49 (0)89 2180-2740, Telefax +49 (0)89 2180-17845, email office@cesifo.de

Editor: Clemens Fuest

www.cesifo-group.org/wp

An electronic version of the paper may be downloaded

- from the SSRN website: www.SSRN.com

- from the RePEc website: www.RePEc.org

- from the CESifo website: www.CESifo-group.org/wp 


\title{
Revealed Political Favoritism: Evidence from the Allocation of State Lottery Grants in Israel
}

\begin{abstract}
This paper offers a complementary empirical approach that might be better suited to identify the extent of political favoritism in a multi-decision-maker institution than the standard identification strategy. The typical diff-in-diff identification strategy to estimate political favoritism, which rests on a comparison of two decision makers that allocate public funds to two groups, seems inadequate in a multi-player setting due to the multiple and conflicting political interests and social affiliations. To illustrate how our approach uncovers the degree of political favoritism, we use a policy change in allocating state lottery revenues to Israeli municipalities from discretion-based allocation to rules-based allocation. We find significant political favoritism under the old regime relative to the new one toward Jewish (versus Arab) and affluent (versus less affluent) municipalities. Our results suggest that adopting rules-based allocation might be effective in coping with political favoritism.
\end{abstract}

Keywords: political favoritism, grant allocation, local government, rules vs. discretion.

Momi Dahan

School of Public Policy \& Government

Hebrew University

Jerusalem / Israel

momi.dahan@mail.huji.ac.il
Itamar Yakir

School of Public Policy \& Government

Hebrew University

Jerusalem / Israel

itamar.yakir@mail.huji.ac.il 


\section{Introduction}

A large body of research has identified various channels through which political favoritism is executed but might not capture the complete picture due to limitations of methodology. The standard identification strategy may be adequate for detecting a particular mechanism through which political favoritism is manifested but may fail to catch the overall effect of favoritism due to the many motivations underlying politicians' behavior and the complexity of the decisionmaking of multi-player institutions. Public organizations most commonly include several players and hence also multiple and diverse social affiliations and political interests. These political players may trade political favors, which makes the traditional empirical identification even less suitable to uncover the overall political favoritism.

To estimate the degree of political alignment and political favoritism, the typical diff-in-diff identification strategy examines the behavior of two decision makers that allocate public resources and differ in a particular dimension (first difference), and that difference is compared with the gap in public funds received by two groups or lower political levels that differ in that same dimension (second difference). For example, a politician at the central level may allocate more public funds to certain localities with mayors of the same political party (political alignment) to increase the chances of winning future elections (electoral motivation). Many empirical studies lend support to this type of motivation. To name only a few, Migueis (2013) found that politically aligned localities in Portugal (1992-2005) received 19\% more transfers than unaligned localities. Solé-Ollé and Sorribas-Navarro (2008) found that aligned localities in Spain (1993-2003) received 40\% extra transfers from central and regional levels. Results of similar form and magnitude were found by Bracco et al. (2013) for Italy (1998-2010): 41\% extra funds to aligned localities and a $28 \%$ higher probability to be re-elected. Political alignment in the central-local government context, and a corresponding favoritism, have also been observed in other developed countries such as the United States (Berry et al. 2010, Albouy 2013), Canada (Milligan \& Smart 2005), France (Fabre \& Sangnier 2017), Norway (Fiva \& Halse 2016), Belgium (Jennes \& Persyn 2015) and Israel (Rozevitch \& Weiss 1993, Alperovich 1984) and 
developing and emerging economies such as Chile (Toro, 2019), Indonesia (Gonschorek et al. 2018), Brazil (Brollo \& Nannicini 2012), India (Pande 2003).

Employing the same identification strategy, studies published in recent years have expanded this literature and highlighted that politicians might allocate public funds according to identity affiliation, even without serving direct or indirect electoral interests. Hodler and Raschky (2014) found that the birth region of the country's political leader is significantly favored during his term, based on a large inter-country setup (126 countries, 1992-2009). They showed that this is the case especially for countries with autocratic regimes, weak political institutions, and lesseducated citizens. Nevertheless, social identity has also been proven to play a role in more developed and democratic countries. Carozzi and Repetto (2016) found that Italian members of parliament (1994-2006) tend to favor their birth towns when these towns are outside their district of election. This favoritism was proven to be resilient only when elections were not in sight, suggesting that personal sentiments are given place (at least) when not competing with political interests. In a similar manner, Fabre and Sangnier (2017) analyzed the behavior of French ministers with regard to discretionary investment grants (2000-2013) and found that political interests dominate the personal ones. Testing for both birth town bias and for favoritism toward municipalities in which the ministers held office, they found the latter to have a dramatic effect ( $+45 \%$ in funds) but not the former. Additionally, Asatryan and Halvik (forthcoming), for a large all-European setup (1959-2016), found that national representatives to the European Investment Bank utilize their position to favor specific regions more than other regions in their countries. ${ }^{1}$

In this paper, we offer a complementary approach to identify the extent of revealed political favoritism by estimating the difference in public funds granted by decision makers in two different regimes (rather than politicians): discretion-based allocation and rules-based allocation of state lottery funds in Israel. To uncover political favoritism, we compare the likelihood of

\footnotetext{
${ }^{1}$ Identity affiliation might be more important relative to political affiliation in countries where the control and presence of parties at the local level are weak. That is why in countries like Spain (Solé-Ollé \& Sorribas-Navarro, 2008) and Portugal (Migueis, 2013) that are characterized by a strong party discipline on the part of local players, the identity affiliation might be somewhat restrained relative to countries where the grip of parties at the local level is weaker, as in the case of Israel (Kenig \& Tuttnauer 2015) and Italy (Gamalerio 2017). Interestingly, for autocratic regimes where there is no effective party division, and hence weaker importance of political (party) affiliation, identity in the broader sense should again be important, as in the case of Vietnam (Do et al. 2017).
} 
receiving grants by disadvantaged localities versus more affluent localities before and after the shift to formula-based allocation. Under our identification approach, the emphasis shifts from process to outcome, leaving the sources of political favoritism covered. This is why we label it revealed political favoritism.

Our approach employs the same diff-in-diff methodology but without the need to be bounded by the characteristics of politicians or one particular interest or social affiliation. The suggested identification strategy allows multiple political interests and competing identifiers such as gender, place of birth, religious and social group affiliation (with different unobserved weights) to affect overall political favoritism. Unlike the traditional identification strategy, our approach can be used even in the case of no exogenous variation in political or social affiliations of the collective decision-making body. Our study illustrates that political favoritism toward a certain social affiliation (e.g., Jewish localities) might be estimated despite the stable religious composition of the board of directors observed over time (one Arab member in most years).

Based on this approach, our results show that under a discretionary regime, the state lottery board tended to prefer economically stronger and Jewish localities. Less populated localities seem to have been favored in the first period, but being a geographically remote locality does not appear to affect the probability of receiving a grant. Employing the standard identification strategy does not detect political favoritism, which suggests that previous studies may have underestimated the overall political favoritism.

The rest of the article is structured as follows. Section 2 presents the institutional background, focusing on the institutional environment that paved the way for the policy changed discussed in the article. Section 3 presents the data and some descriptive statistics, and Section 4 includes the methodological strategy. Section 5 presents the results, and Section 6 offers a short discussion of the results and conclusions. 


\section{Institutional background}

The state lottery (Pais) was established in 1951 as an instrument to finance municipal infrastructures in the city of Tel Aviv. It has since expanded dramatically and is now a nationwide authorized gambling platform activating through almost 2,500 selling points. Over the years, the legal status and the public image of the organization became a disputable issue. In 2016, the total revenues of the Pais reached 6.7 billion shekels (1.9 billion dollars), larger than the total annual budget of the welfare ministry in the same year (6.4 billion). In the same year, 4.3 billion shekels of its revenues were allocated in the form of prizes to gamblers. Of the remaining sum, 1.3 billion shekels were allocated in the form of grants. These grants were designated to finance the erection of schools and kindergartens (0.82 billion); physical infrastructure for sport and cultural activities in municipalities (0.82); and an additional 0.14 billion for other purposes, including scholarships and prizes in the fields of art, literature, academia, and the like. Most of the grants expire after a few years if not utilized. The grants to localities in the final years studied in this research are similar in magnitude to the annual government expenditures on culture (see ICBS, 2018).

Since 2002, the allocation of the grants by the Pais has been based on a transparent formula, which has replaced the previous discretion-based policy that was determined by its board of directors. The adoption of the rule followed the recommendations of a public committee that was established based on public and state comptroller criticism regarding suspected biased allocation by the Pais. That policy change was part of a more general trend of Israeli authorities at that time toward rules-based policy in several areas, such as a deficit-reduction rule in 1992, an expenditure rule in 2004 (Ben-Bassat and Dahan 2006), and a new “equalization grants” formula also enacted in 2004 for grants allocated from the central government to localities in response to fiscal instability (Ben-Bassat et al. 2016).

Promoting equality and impartiality was the main motivation behind the shift to rules-based policy. $^{2}$ The new formula for allocating Pais grants to municipalities includes 4 components,

\footnotetext{
${ }^{2}$ Interestingly, Dahan and Strawczynski (2013) showed that fiscal rules may improve fiscal discipline but at the cost of wider economic disparities.
} 
each receiving a different weight: the number of residents in a municipality (50\%); municipality rank on the Socioeconomic Index (SEI, 25\%) and municipality rank on the Peripheral Index (20\%), ${ }^{3}$ both on a 1-10 scale; and the share of young cohorts serving in the army (or in civil service) in the municipality (5\%). ${ }^{4}$ Thus, the formula is constructed to give priority to economically disadvantaged localities and to localities located in the geographical periphery of the country.

As mentioned above, according to the old regime, the allocation of grants was determined by the Pais board, which includes 8-13 members. Two to three members represent the central government; 4-6 are acting mayors, serving for an average period of 5 years; and another 3 are mayors or treasurers of the three big cities in Israel (Jerusalem, Tel Aviv, and Haifa). In 2013, a public representative joined the board. Overall, the local government has a significant majority on the board, though the chairman of the board is directly appointed by the prime minister. Of the local representatives, four are ex-officio members, and the rest are changing members. The changing members of the board are jointly appointed by (a) the minister of interior and the minister of finance; (b) the head of the regional councils organization; (c) the mayors of the three big cities; and (d) the head of the municipalities' union (also a mayor). The last four are permanent (ex-officio) members of the board. Such a board of directors represents multiple and conflicting political interests and identities, which undermines the standard identification strategy as a tool for uncovering the overall extent of political favoritism.

\section{Data}

Data on grants by municipality for 26 years (1990-2015) were provided by the Pais (Table 1). These data are complemented by geographical and other sociodemographic data on the 256

\footnotetext{
${ }^{3}$ The Peripheral Index is composed of the distance from Tel Aviv and an accessibility measure and available for the years 2004 and 2015 (the methodology for computing this index was slightly modified in 2015). The Socioeconomic Index (SEI) is composed of 14 sub-components and is calculated every 3 years. For specific purposes, when stated, the 2008 SEI value was used. Otherwise, the closest available SEI value was used.

${ }^{4}$ For a few years, the formula also included an additional component: the monetary value of existing physical infrastructure in the municipality (weighted at $10 \%$ ). This component was later canceled, and the $10 \%$ was added to the Peripheral Index component, which until then was given a weight of $10 \%$.
} 
municipalities from the Israel Central Bureau of Statistics (ICBS). The first six years of the data show a seemingly sharp expansion in total resources allocated and in the number of localities involved (see Figure 1), but this might reflect partially improved data collection as this increase in grants outperformed the actual growth in Pais revenues. That is why the main empirical analysis is based on the period starting in 1996. For robustness checks, we also estimate the degree of political favoritism for the full period (starting in 1990). Note that the average grant per capita is quite stable over the full period when only conditional grants are calculated (Figure 1). The average positive grant per capita in the second period is lower by about $14 \%$ relative to the first period. This change is expected in light of the universal formula in the second period that enabled a larger number of localities to qualify for a grant.

The data we use reflect the grants that were translated into actual projects rather than the allocated grants. In the empirical analysis, we assume that the gap between actual and allocated grants is not correlated with the characteristics of localities. Nevertheless, the empirical analysis addresses a potential association along ethnic lines between the two regimes.

To give a general impression of the allocation of the funds before and after the policy change, we provide some descriptive statistics. The distribution of the total sum of grants before and after the change is graphically demonstrated below and provides a basic indication of the rule's impact. Figure 2 shows that the ratio between the probability of a poor locality (belonging to the lowest 1-3 socioeconomic deciles) to receive a grant relative to the probability of all other localities (upper 4-10 deciles) goes up from 63\% in the first period to close to $90 \%$ in the second period. The unconditional probability to receive a grant increased after the move to a rules-based regime for the bottom two socioeconomic deciles and decreases for all other deciles. The reduction for the upper 8 deciles is larger the higher the socioeconomic decile is, except for the top decile (Table 2). The sharp decline in political favoritism toward more affluent municipalities is also observed in terms of grants per capita; the ratio of grants per capita in municipalities in the bottom 1-3 to the upper 4-10 socioeconomic deciles increases from 1.1 to 1.6 following the policy change. Theses results, however, might be driven by other characteristics, such as population size and ethnic composition, which will be addressed in the empirical analysis. 
Figure 3 shows a fall in political favoritism toward localities with a Jewish majority following the policy change. The ratio between the probability to receive a grant of localities with an Arab majority to that of Jewish localities increased from $46 \%$ to $65 \%$. Note that Arab municipalities are less likely to get grants even after the policy change. However, conditional on receiving a grant, the grant per capita in Arab municipalities relative to Jewish municipalities is only slightly higher in the rules-based regime compared to the old regime. Note that Arab municipalities receive a higher grant per capita relative to Jewish municipalities, but it seems to reflect economies of scale in grants. Table 2 (panel B) shows a clear pattern of economics of scale: per capita grants decrease as the population size of a municipality increases. Thus, the difference in grant per capita between the two groups does not take into account the number of residents, which is significantly smaller in Arab municipalities (as compared to Jewish). Again, the empirical analysis would take into account other factors that may be responsible for these correlations, as Arab localities, for example, are significantly poorer and smaller in terms of population relative to Jewish localities.

Table 2 does not present a noticeable change in the likelihood of receiving a grant after the policy change by the other two municipality characteristics: the degree of peripheral location and the population size (smaller municipalities gain somewhat less).

\section{Methodology}

To uncover the extent of political favoritism, we estimate the change in the probability of receiving state lottery grants by two types of localities (by either socioeconomic index, ethnicity, population size or geographic location) in the rules-based period relative to the discretion-based period. We also use the same diff-in-diff identification technique to estimate political favoritism, replacing the probability of receiving state lottery grants by grants per capita conditional on receiving a grant. The following statistical model is estimated:

$$
\text { Received }_{c t}=\beta_{0}+\beta_{1} X_{c t}+\beta_{2} \text { Post }+\beta_{3} M G_{c t}+\beta_{4}\left(\text { Post } \times M G_{c t}\right)+\gamma_{c}+\text { Year }_{t}+\varepsilon_{c t}
$$


where Recieved $d_{c t}$ (the outcome of interest) is a binary variable that equals 1 when locality $c$ receives a grant at time $t . X_{c t}$ is a vector of time-varying control variables, ${ }^{5} \gamma_{c}$ is the municipality

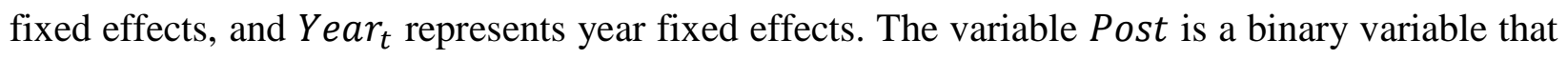
receives a value of 1 for the second period (i.e., after the adoption of the rule). We define the post-treated period in our analysis as the years 2005-2015, starting three years after the actual shift to rules-based allocation, to account for the time gap between the instance the grant was allocated (unobserved) and the time the project took place, which has been documented in the Pais dataset. The baseline analysis is based on three years gap as it takes more than two years (on average) to finish a building in Israel.

The variable $M G$ (municipalities group) receives a value of 1 if the municipality belongs to a specific group of municipalities, when $M G_{c t} \in\{$ Arab, SEI, Peripheral,PopSize $\}$. In each case, we identify a group of municipalities by a binary variable. In one case, we compare Arab to Jewish municipalities (Arab $=1$ ), and in the three other cases, we compare municipalities that belong to the 3 bottom (the omitted group is the 7 top deciles) in terms of three different characteristics (socioeconomic rank, Peripheral Index, and population size). We test below different groupings (bottom two, bottom four, etc.) to examine the sensitivity of our results. The coefficient $\beta_{4}$ on the interaction term (Post* $\mathrm{MG}_{\mathrm{ct}}$ ) is the focus of our analysis, as it captures the effect of moving between allocation regimes for a specific group of municipalities.

Given that achieving impartiality was the main intention behind the shift to a rules-based allocation policy, we consider these four social and economic characteristics of localities in estimating the degree of political favoritism. The attitude toward each of the four groups may represent either political interests or identity affiliations, or some of both. The first characteristic that we explore to uncover political favoritism is the socioeconomic rank of a municipality. More affluent municipalities are expected to benefit more under discretion-based policy. Note that economically weaker localities bear a bigger share of the burden of gambling in Israel. As shown by Dahan (2019), low-income areas are disproportionately responsible for generating the

\footnotetext{
${ }^{5}$ We control for population and for the other factors included in the formula. Specifically, when the main independent variable examined is low socioeconomic decile, we also control for the value of the Peripheral Index and for the ethnic majority in the locality.
} 
gambling revenues. The ethnicity (Jewish versus Arab) of the majority of municipality residents is our second characteristic. Jewish versus Arab municipalities is a natural candidate for identitybased political favoritism in light of the tensions between these two ethnic groups in Israel. ${ }^{6}$ The third characteristic is the population size. One could suggest that more populated municipalities may get more resources due to their share in the popular vote and better bureaucratic capacity. As mentioned in the institutional background section, the largest cities are overrepresented on the Pais board of directors, which might be used to channel more grants to populated municipalities under the discretion-based regime. Last, the discretion-based regime might be exploited to favor municipalities at the center of the country compared to remote municipalities. Three of the four characteristics considered (socioeconomic status, peripheral location, and population size) are explicitly included in the formula adopted.

As described earlier, the formula states that the level of grants should be proportional to population size and negatively related to socioeconomic ranking and the Periphery Index. Thus, a zero coefficient on the interaction term $\left(\beta_{4}\right)$ implies the same degree of political favoritism, and the new regime only reflects a formulation of the previous discretion-based allocation policy. For example, the representatives of the large cities may shape the allocation formula to keep their share in grants. In contrast, a positive (negative) coefficient suggests that previous allocation policy favors (disfavors) the better off localities.

\section{Results}

We first consider the standard identification strategy by estimating the effect of the policy change on localities whose mayor has been a member of the Pais board of directors throughout the period of the study. We specifically construct this binary variable to identify localities whose mayors have ever been on the board, not necessarily around the years when the locality received grants. Thus, we also account for the possibility of mayors trading favors over time. We find no

\footnotetext{
${ }^{6}$ A municipality with $50 \%$ or more of Arab residents is defined here as an Arab municipality. Except for a few localities with a small to medium Arab minority, almost all the localities in Israel are either predominantly Jewish or predominantly Arab.
} 
significant effect on the probability of grant-receiving (Table 3: panel A) or on the level of grants per capita for this group of localities (Table 3: panel B). This identification strategy might not detect political favoritism, despite its existence, due to complex trading of favors between the members of the board who represent multiple political interests and social affiliations and the results in Table 3 illustrates the limitations of the standard identification strategy. Against this background, we now turn to our approach, which estimates political favoritism by comparing the funds granted before and after the policy change to groups of localities based their characteristics, regardless of the personal characteristics of the decision makers.

Estimates for the probability of economically weak localities to receive a grant imply that disfavoring this group in the first period occurs at a magnitude of 11-16\% (Table 4). This finding emerges in all six models. Models 1-4 are linear probability models (LPMs), while models 5 and 6 are standard fixed effects models. ${ }^{7}$ The results for the grants per capita are also positive and significant (panel B of Table 4), suggesting a reduction in political favoritism toward more affluent municipalities following the policy change.

The fall in political favoritism as a result of the shift to rules-based allocation is also observed when examining ethnicity (after controlling for the socioeconomic status, population size, and geographic remoteness). The positive and significant coefficient of the interaction between Arab and Post suggests that Arab municipalities have benefited from the policy change by 6-8\% (Table 5: panel A). This ethnic dividend of the move to rules-based allocation is important given the fact that the ethnic origins of municipality residents were not directly included in the new formula. We do not find a significant effect on the grants per capita regressions (Table 5: panel B). We speculate that the gap in the probability of receiving a grant in favor of Jewish localities found here might be less detectable and therefore more prone to political favoritism than a gap in grants per capita in receiving localities. In contrast, differences in grants per capita are more visible and are easily calculated and therefore are less suitable candidates to direct more funds to favored groups.

\footnotetext{
${ }^{7}$ Models 2-4 include controls in the form of binary variables only (variables that equal one for the upper half of the distribution), and models 5-6 include continuous variables.
} 
The likelihood of receiving a grant is not affected by geographic remoteness, as implied by the estimated coefficients (Table 6). Peripheral localities are not favored or disfavored after the policy change compared to the first period in terms of probability to receive grants. No significant effect is found also using grants per capita instead of the likelihood of receiving a grant. The policy change also seems to have no effect on the degree of political favoritism toward large municipalities (relative to small ones) in terms of both the probability to get a grant and grants per capita conditional on receiving a grant (Table 7).

Next, we examine the robustness of the results regarding the reduction in political favoritism toward Jewish and more affluent municipalities following the change from discretion-based to rules-based allocation. First, given that the available data represent the time the grant was utilized, we previously assumed that the time window between the decision to allocate a grant until the actual project took place was three years, so that the discretion period ends in 2001 but the rules-based period starts only in 2005. Our findings regarding the decline in political favoritism toward Jewish and more affluent municipalities are robust to shorter time windows, such as one year and two years (Table 8). Note that this finding rests on the idea that the capacity of a specific group of localities (e.g., Arab localities) to utilize grants received has not improved between the two periods relative to other localities, which is a plausible assumption. ${ }^{8}$

Second, our choice to represent municipalities of low socioeconomic status by the bottom three deciles should be tested. In Table 9, we estimate political favoritism using separately the bottom decile, the bottom two deciles, and so on, up to the bottom five socioeconomic deciles, avoiding ex-ante arbitrary grouping. As can be seen, the results are not sensitive to the choice of grouping. As expected, we observe a fall in the size of the coefficient as higher deciles are included in the "treated" group.

Third, we estimate the degree of political favoritism for the entire period, including the first six years (1990-1995). Using the full period, Table 10 shows that the bottom three socioeconomic

\footnotetext{
${ }^{8}$ A study done by the Research \& Information Center of the Israeli parliament (the Knesset) to examine a potential bias against Arab localities in allocating Pais grants found that grants in the years 2011-2015 (in the second period in our study) were proportional to their relative share in the population but that Arab localities were characterized by lower rates of grant utilization.
} 
deciles (relative to the upper 7 deciles) have benefited from the adoption of rules-based policy. The results are robust for both the probability to receive a grant and the level of grants per capita. Fourth, the coefficient on the interaction between Arab and Post continues to be positive but borderline significant in three specifications when the investigated period covers the first six years and the dependent variable is the probability of receiving a grant (Table 10). To further explore the sensitivity of our finding regarding political favoritism toward Jewish municipalities (in terms of the likelihood to get a grant), we estimate our baseline regressions excluding the first year, first two years, and so on. We find that the coefficient is significant in most specifications, except for the first 2 years (Table 11).

\section{Summary and Conclusions}

In this paper, we deviate from the standard identification strategy to uncover political favoritism. Our complementary approach to identify the extent of political favoritism estimates the gap in public funds granted to two groups in two different regimes (rather than politicians). The standard identification strategy may fail to account for the multiple political interests and social affiliations of decision makers in public bodies. As a result, such an empirical strategy may not capture the full extent of political favoritism. It is also less suitable to assess political favoritism in the case of small or no exogenous variation in personal characteristics of politicians.

Our identification approach copes with these limitations by comparing two different grantallocation regimes, rather than two types of politicians. It allows us to estimate the overall or revealed political favoritism, but at the cost of keeping the underlying mechanism behind favoritism vague. Thus, the outcome rather than the process is at the center of this empirical strategy.

The standard identification strategy may be adequate for detecting a particular mechanism through which political favoritism is manifested but may fail to catch the overall effect of favoritism due to the many motivations underlying politicians' behavior and the complexity of the decision-making of multi-player institutions. Public organizations most commonly include several players and hence also multiple and diverse social affiliations and political interests. 
These political players may trade political favors, which makes the traditional empirical identification even less suitable to uncover overall political favoritism.

We employ this methodological approach to examine political favoritism based on a policy shift from discretion-based allocation to rules-based allocation of state lottery funds in Israel (Israeli mayors held the authority to decide the allocation of grants to localities in the country). We find that Arab localities have benefited from this policy change, which means that the old regime was associated with a higher degree of political favoritism toward Jewish localities. We also uncover that discretion-based allocation disfavors economically weak and favors less populated localities relative to rules-based allocation. Being located in the geographical periphery seems to be unrelated to higher chances of being favored or disfavored in terms of the probability to receive a grant. Our results are valid as long as the utilization rates of Arab localities (or small, peripheral, etc.) have not increased relative to other localities between the two regimes.

The findings of our research suggest that the adoption of rules-based allocation is an effective policy in enhancing equity. This is even more important in view of the relative position of Arab citizens and the heated tension between Jews and Arabs in Israel. 


\section{References}

Albouy, D. (2013), 'Partisan representation in Congress and the geographic distribution of Federal funds', Review of Economics and Statistics 95(1), 127--141.

Alperovich, G. (1984), 'The economics of choice in the allocation of intergovernmental grants to local authorities', Public choice 44(2), 285--296.

Asatryan, Z. \& Havlik, A. (2018), 'Multilateral Lending to European Regions: who gets the funds and what are the effects?', unpublished manuscript.

Ben-Bassat, A., \& Dahan, M. (2006). The balance of power in the budgeting process. The Israeli Democracy Institute.

Ben-Bassat, A.; Dahan, M. \& Klor, E. F. (2016), 'Is centralization a solution to the soft budget constraint problem?', European Journal of Political Economy 45, 57--75.

Berry, C. R.; Burden, B. C. \& Howell, W. G. (2010), 'The president and the distribution of federal spending', American Political Science Review 104(4), 783--799.

Bracco, E.; Porcelli, F. \& Redoano, M. (2013), 'Incumbent effects and partisan alignment in local elections: a regression discontinuity analysis using Italian data', CESifo Working Paper Series.

Brollo, F. \& Nannicini, T. (2012), 'Tying your enemy's hands in close races: the politics of federal transfers in Brazil', American Political Science Review 106(4), 742--761.

Carozzi, F. \& Repetto, L. (2016), 'Sending the pork home: Birth town bias in transfers to Italian municipalities', Journal of Public Economics 134, 42--52.

Dahan, M. (2019), 'Using Spatial Distribution of Outlets to Estimate Gambling Incidence', forthcoming in Israel Economic Review.

Dahan, M. \& Strawczynski, M. (2013), 'Fiscal rules and the composition of government expenditures in OECD countries', Journal of Policy Analysis and Management 32(3), 484--504.

Do, Q.-A.; Nguyen, K.-T. \& Tran, A. N. (2017), 'One Mandarin Benefits the Whole Clan: Hometown Favoritism in an Authoritarian Regime', American Economic Journal: Applied Economics 9(4), 1-29.

Fabre, B. \& Sangnier, M. (2017), 'What Motivates French Pork: Political Career Concerns or Private Connections?', Archive ouverte en Sciences de l'Homme et de la Societe.

Fiva, J. H. \& Halse, A. H. (2016), 'Local favoritism in at-large proportional representation systems', Journal of Public Economics 143, 15--26.

Gamalerio, M. (2017), 'Do national political parties matter? Evidence from Italian 
municipalities', unpublished manuscript.

Golden, M. \& Min, B. (2013), 'Distributive politics around the world', Annual Review of Political Science 16, 73--99.

Gonschorek, G. J., Schulze, G. G., \& Sjahrir, B. S. (2018). To the ones in need or the ones you need? The political economy of central discretionary grants- empirical evidence from Indonesia. European Journal of Political Economy, 54, 240-260.

Hodler, R. \& Raschky, P. A. (2014), 'Regional favoritism', The Quarterly Journal of Economics 129(2), 995--1033.

Israel Central Bureau of Statistics (ICBS); The Open Budget Project, retrieved: 22/11/2018

Jennes, G., \& Persyn, D. (2015). The effect of political representation on the geographic distribution of income: Evidence using Belgian data. European Journal of Political Economy, 37, 178-194.

Kenig, O. \& Tuttnauer, O. (2015), 'The decline of the large mainstream parties', The Elections in Israel, 21--46.

Knesset, T. (2016), 'Data on the Pais construction grants to local authorities', Technical report, The Knesset, Research and Information Center.

Lara B. \& Toro, S. (2019). Tactical distribution in local funding: The value of an aligned mayor. European Journal of Political Economy, 56, 74-89.

Migueis, M. (2013), 'The effect of political alignment on transfers to Portuguese municipalities', Economics \& Politics 25(1), 110--133.

Milligan, K. S. \& Smart, M. (2005), 'Regional grants as pork barrel politics', CESifo Working Paper Series No. 1453.

Pande, R. (2003), 'Can mandated political representation increase policy influence for disadvantaged minorities? Theory and evidence from India', American Economic Review 93(4), 1132--1151.

Rozevitch, S. \& Weiss, A. (1993), 'Beneficiaries from federal transfers to municipalities: The case of Israel', Public Choice 76(4), 335--346.

Shahor, T. (2010), 'The Ministry of Iterior's Balance Grant: Does it reduce the inequality between the local government authorities?', The Van Leer Jerusalem Institute, Policy Studies.

Solé-Ollé, A. \& Sorribas-Navarro, P. (2008), 'The effects of partisan alignment on the allocation of intergovernmental transfers. Differences-in-differences estimates for Spain', Journal of Public Economics 92(12), 2302--2319.

Toro, S. (2019). Tactical distribution in local funding: The value of an aligned mayor. European 
Journal of Political Economy, 56, 74-89. 
Figure 1: Annual state lottery grants, 1990-2015
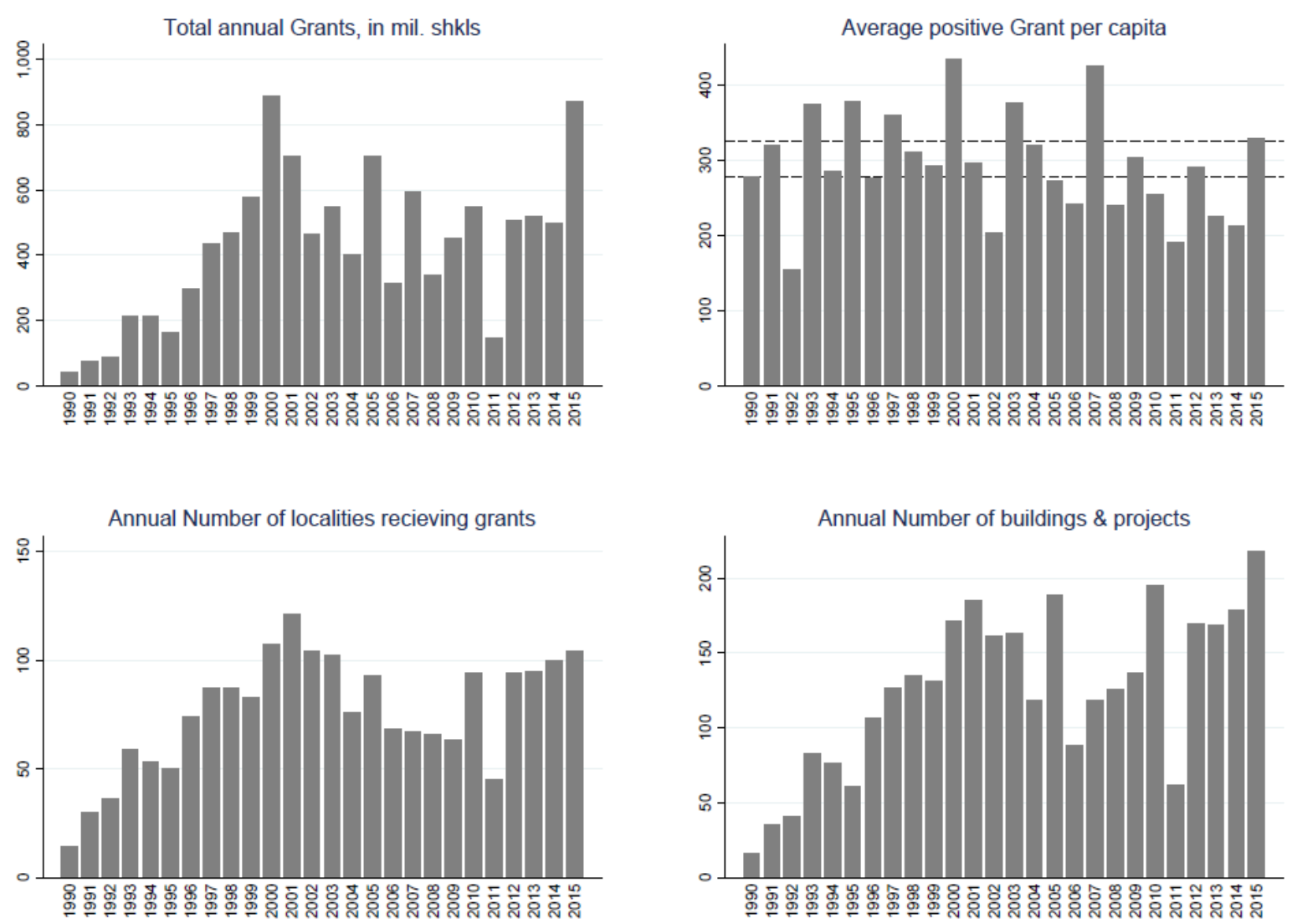

Note: The horizontal lines in the top-right panel is the average grant per capita in each sub-period: the upper line is the first period and the bottom line is the second period. 
Figure 2: Unconditional ratio of the bottom 3 deciles in the Socioeconomic index to deciles 4-10, 1996-2001 vs. 2005-2015
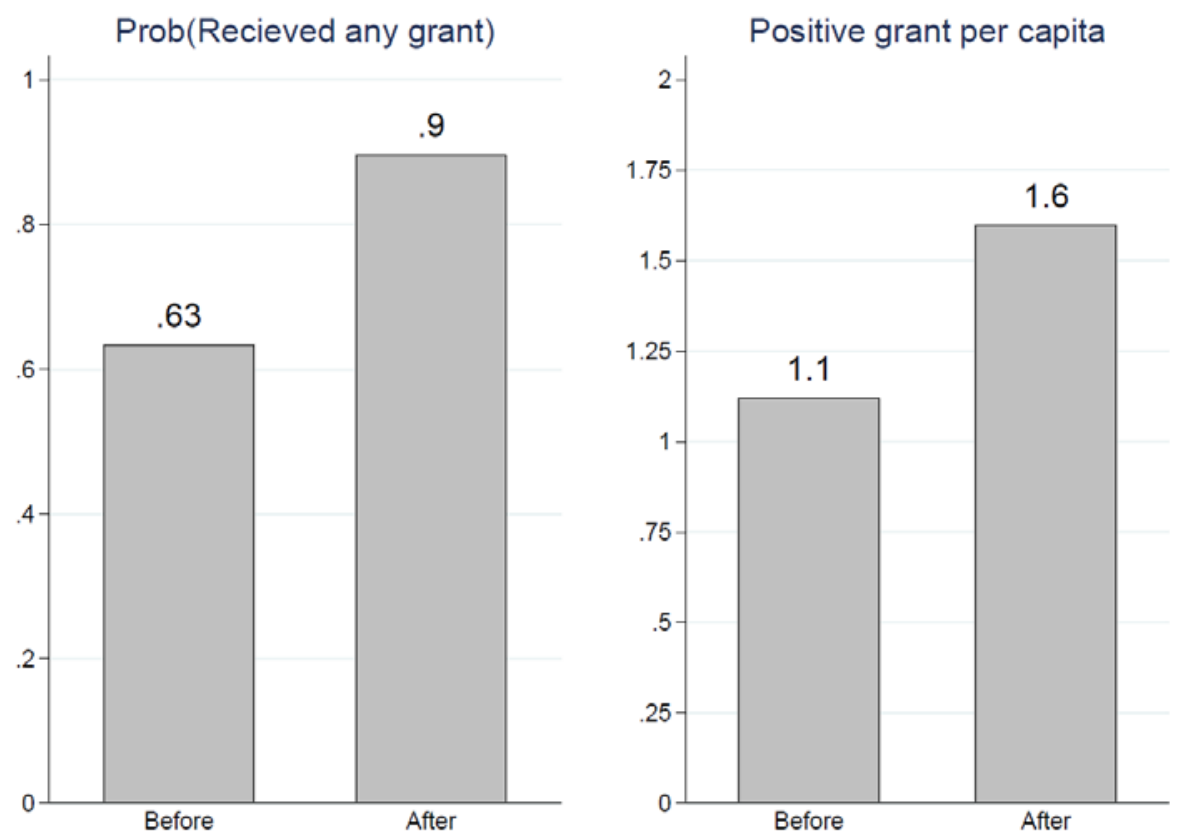

Note: in order to keep for stable composition of the localities, the Socioeconomic index used for this chart is that of 2008.

Figure 3: Unconditional ratio of Arab localities relative to Jewish localities, 1996-2001 vs. 2005-2015
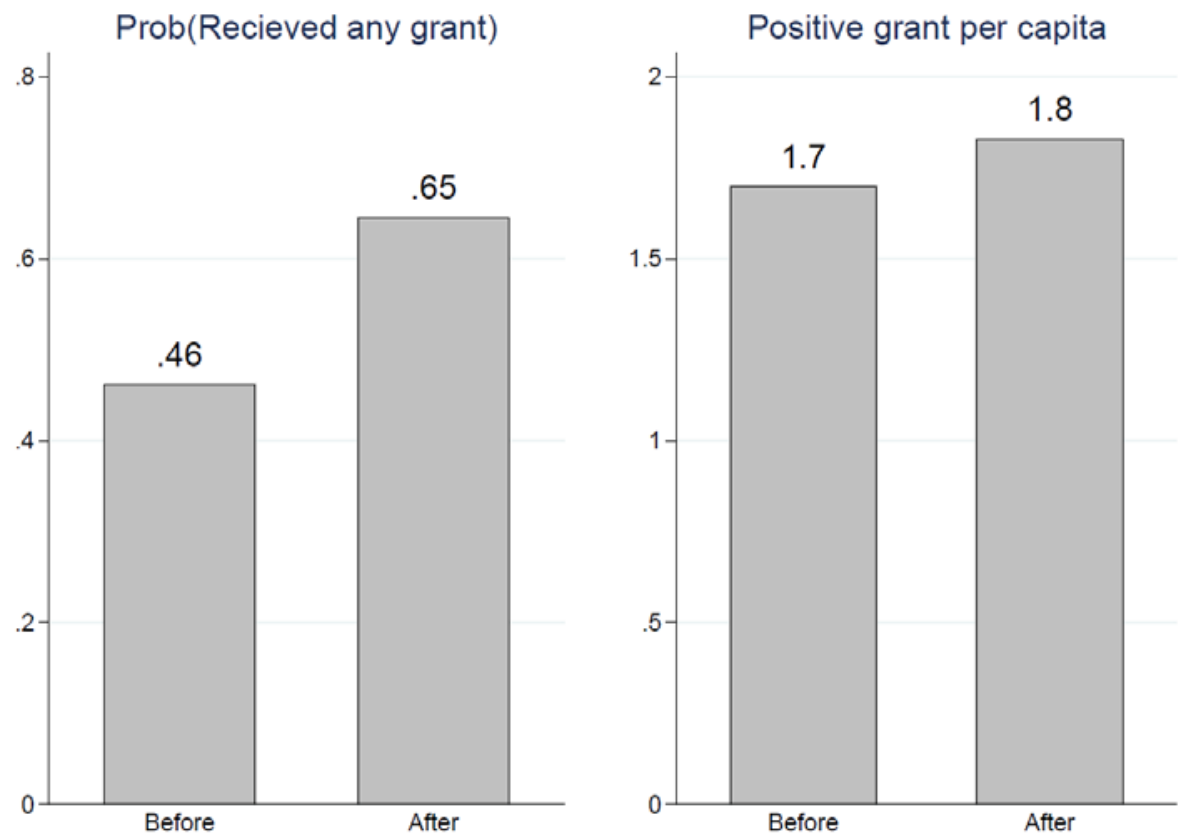

Note: Localities identified by majority. 
Table 1: Descriptive statistics (1990-2015)

\begin{tabular}{llllll}
\hline Variable & $\mathrm{N}$ & Mean & SD & min & max \\
\hline Received any grant & 6604 & 0.3 & 0.46 & 0 & 1 \\
Grant ('000 shekels) & 6473 & 1,700 & 5,000 & 0 & 74,000 \\
Grant per capita & 6461 & 90.15 & 311.6 & 0 & 8,016 \\
Positive grant per capita & 1960 & 297.1 & 508.5 & 1 & 8,016 \\
Number of buildings (projects) & 6604 & 0.49 & 1.1 & 0 & 25 \\
Mayor ever on board* & 6604 & 0.087 & .28 & 0 & 1 \\
An Arab municipality & 6604 & 0.33 & 0.47 & 0 & 1 \\
Socioeconomic index & 6520 & -.034 & .98 & -3.08 & 3.5 \\
Socioeconomic index 2008 & 6489 & .0018 & 1.0 & -3.08 & 3.5 \\
Peripheral Index & 6489 & -.0078 & .922 & -3.0 & 2.73 \\
Population ('000) & 6423 & 26.6 & 60.6 & 0.2 & 849.8 \\
\hline
\end{tabular}

* Excluding mayors of the three big cities that are constantly members of the board. 
Table 2A: The change in share of localities that received any grant in each of the periods (1996-2001 vs. 2005-2015), by socioeconomic rank, geographical location and population size (change shown in percentage points)

\begin{tabular}{llll|lll|lll}
\hline & \multicolumn{3}{c}{ SEI } & \multicolumn{3}{c|}{ Peripheral } & \multicolumn{3}{c}{ Population Size } \\
& Before & After & $\Delta$ & Before & After & $\Delta$ & Before & After & $\Delta$ \\
\hline 1 & 0.24 & 0.36 & 0.12 & 0.24 & 0.20 & -0.04 & 0.12 & 0.10 & -0.02 \\
2 & 0.19 & 0.21 & 0.02 & 0.32 & 0.21 & -0.11 & 0.21 & 0.17 & -0.04 \\
3 & 0.33 & 0.31 & -0.02 & 0.29 & 0.32 & 0.03 & 0.18 & 0.19 & 0.01 \\
4 & 0.43 & 0.36 & -0.07 & 0.3 & 0.28 & -0.02 & 0.20 & 0.23 & 0.03 \\
5 & 0.44 & 0.39 & -0.05 & 0.35 & 0.24 & -0.11 & 0.26 & 0.23 & -0.03 \\
6 & 0.47 & 0.38 & -0.09 & 0.41 & 0.37 & -0.04 & 0.38 & 0.31 & -0.07 \\
7 & 0.51 & 0.32 & -0.19 & 0.47 & 0.41 & -0.06 & 0.41 & 0.36 & -0.05 \\
8 & 0.44 & 0.33 & -0.11 & 0.33 & 0.38 & 0.05 & 0.54 & 0.44 & -0.10 \\
9 & 0.44 & 0.31 & -0.13 & 0.48 & 0.39 & -0.09 & 0.55 & 0.54 & -0.01 \\
10 & 0.25 & 0.23 & -0.02 & 0.59 & 0.43 & -0.16 & 0.82 & 0.62 & -0.20 \\
Bottom3 & 0.25 & 0.30 & 0.05 & 0.28 & 0.24 & -0.04 & 0.17 & 0.15 & -0.02 \\
Deciles 4- & 0.42 & 0.33 & -0.09 & 0.40 & 0.35 & -0.05 & 0.45 & 0.39 & -0.06 \\
\hline 10
\end{tabular}

\begin{tabular}{lllr}
\hline Arab & 0.22 & 0.23 & 0.01 \\
Jewish & 0.44 & 0.36 & -0.08 \\
average & 0.37 & 0.32 & -0.05 \\
\hline
\end{tabular}

Notes: The SEI value used here is for the year 2008; and population size is the average size over each of the periods. 
Table 2B: The change in grant per capita in each of the periods (1996-2001 vs. 2005-2015), by socioeconomic rank, geographical location and population size

\begin{tabular}{|c|c|c|c|c|c|c|c|c|c|}
\hline & \multicolumn{3}{|c|}{ SEI } & \multicolumn{3}{|c|}{ Peripheral } & \multicolumn{3}{|c|}{ Population Size } \\
\hline & Before & After & $\Delta$ & Before & After & $\Delta$ & Before & After & $\Delta$ \\
\hline 1 & 482 & 420 & $-13 \%$ & 483 & 263 & $-46 \%$ & 1000 & 866 & $-13 \%$ \\
\hline 2 & 432 & 411 & $-5 \%$ & 515 & 269 & $-48 \%$ & 569 & 620 & $9 \%$ \\
\hline 3 & 309 & 290 & $-6 \%$ & 506 & 404 & $-20 \%$ & 612 & 586 & $-4 \%$ \\
\hline 4 & 315 & 214 & $-32 \%$ & 428 & 364 & $-15 \%$ & 688 & 325 & $-53 \%$ \\
\hline 5 & 287 & 218 & $-24 \%$ & 316 & 294 & $-7 \%$ & 367 & 321 & $-13 \%$ \\
\hline 6 & 254 & 173 & $-32 \%$ & 230 & 280 & $22 \%$ & 321 & 287 & $-11 \%$ \\
\hline 7 & 297 & 277 & $-7 \%$ & 396 & 301 & $-24 \%$ & 433 & 246 & $-43 \%$ \\
\hline 8 & 293 & 173 & $-41 \%$ & 323 & 199 & $-38 \%$ & 246 & 216 & $-12 \%$ \\
\hline 9 & 329 & 207 & $-37 \%$ & 275 & 202 & $-27 \%$ & 235 & 169 & $-28 \%$ \\
\hline 10 & 487 & 218 & $-55 \%$ & 123 & 80 & $-35 \%$ & 91 & 81 & $-11 \%$ \\
\hline Bottom3 & 396 & 375 & $-5 \%$ & 502 & 329 & $-34 \%$ & 686 & 659 & $-4 \%$ \\
\hline $\begin{array}{c}\text { Deciles } \\
4-10\end{array}$ & 314 & 232 & $-26 \%$ & 281 & 255 & $-9 \%$ & 275 & 206 & $-25 \%$ \\
\hline Arab & 484 & 416 & $-14 \%$ & & & & & & \\
\hline Jewish & 293 & 228 & $-22 \%$ & & & & & & \\
\hline All & 331 & 272 & $-18 \%$ & & & & & & \\
\hline
\end{tabular}

Notes: The SEI value used here is for the year 2008; and population size is the average size over each of the periods. 
Table 3: Mayors' characteristics and political favoritism, the standard identification strategy

Panel A: Dependent variable: probability to receive a grant

\begin{tabular}{lllllll}
\hline & $(1)$ & $(2)$ & $(3)$ & $(4)$ & $(5)$ & $(6)$ \\
\hline Post & $-0.040^{* *}$ & $-0.083^{* * *}$ & $0.067^{*}$ & $0.124^{* * *}$ & 0.044 & 0.020 \\
& $(0.02)$ & $(0.02)$ & $(0.04)$ & $(0.04)$ & $(0.04)$ & $(0.05)$ \\
Mayor Ever on Board & $0.220^{* * *}$ & $0.122^{* * *}$ & $0.123^{* * *}$ & & & $0.069^{*}$ \\
& $(0.04)$ & $(0.04)$ & $(0.04)$ & & $(0.04)$ & \\
& & & & & & \\
Post X & $-0.103^{*}$ & -0.071 & -0.071 & -0.102 & $-0.094^{*}$ & $-0.094^{*}$ \\
MayorEverOnBoard & $(0.05)$ & $(0.05)$ & $(0.05)$ & $(0.06)$ & $(0.05)$ & $(0.06)$ \\
& & & & & & \\
Constant & $0.348^{* * *}$ & $0.210^{* * *}$ & $0.143^{* * *}$ & $0.307^{* * *}$ & $-1.206^{* * *}$ & $-1.742^{* * *}$ \\
& $(0.01)$ & $(0.01)$ & $(0.03)$ & $(0.03)$ & $(0.07)$ & $(0.42)$ \\
N & & & & & \\
R-sq & 4318 & 4318 & 4318 & 4318 & 4249 & 4250 \\
Controls & 0.012 & 0.106 & 0.125 & 0.033 & 0.173 & 0.040 \\
Year Dummies & No & Yes & Yes & Yes & Yes & Yes \\
Muni. F.E & No & No & Yes & Yes & Yes & Yes \\
\hline
\end{tabular}

Panel B: Dependent variable: $\ln ($ Grant per capita)

\begin{tabular}{lllllll}
\hline & $(1)$ & $(2)$ & $(3)$ & $(4)$ & $(5)$ & $(6)$ \\
\hline Post & $-0.242^{* * *}$ & -0.117 & $0.316^{*}$ & 0.127 & $0.377^{* *}$ & 0.167 \\
& $(0.08)$ & $(0.07)$ & $(0.19)$ & $(0.18)$ & $(0.17)$ & $(0.21)$ \\
Mayor Ever on Board & $-0.500^{* * *}$ & -0.105 & -0.125 & & 0.049 & \\
& $(0.17)$ & $(0.16)$ & $(0.16)$ & & $(0.14)$ & \\
Post X & & & & & & \\
MayorEverOnBoard & 0.202 & 0.033 & 0.037 & 0.027 & 0.076 & 0.026 \\
& $(0.22)$ & $(0.20)$ & $(0.20)$ & $(0.22)$ & $(0.18)$ & $(0.23)$ \\
Constant & & & & & & \\
& $5.073^{* * *}$ & $5.948^{* * *}$ & $5.703^{* * *}$ & $4.577^{* * *}$ & $10.328^{* * *}$ & $5.392^{* *}$ \\
$\mathrm{~N}$ & $(0.06)$ & $(0.08)$ & $(0.16)$ & $(0.17)$ & $(0.32)$ & $(2.36)$ \\
R-sq & & & & & & \\
Controls & 1440 & 1440 & 1440 & 1440 & 1438 & 1438 \\
\hline Not: The & 0.015 & 0.143 & 0.162 & 0.059 & 0.314 & 0.058 \\
& No & Yes & Yes & Yes & Yes & Yes \\
\hline
\end{tabular}

Note: The variable MayorEverOnBoard identifies localities whose mayor has been a member of the Pais board along the period of the study. Control variables include the locality's ethnicity and its ranking in the different measures excluding the one interacted with the Post variable (either population size, geographic location or socioeconomic index). In columns 2-4, the control variables are binary (above and below the median) and in columns 5-6 they are continuous. * Indicates significance level of $10 \%$, ** indicates significance level of $5 \%$. *** Indicates significance level of 1\%. Clustered standard errors are in the parentheses in models 4 and 6 
Table 4: The effect of the policy change on grants, by socioeconomic rank (localities in the bottom 1-3 to upper 4-10 deciles, ranked by socioeconomic index, 1996-2001 versus 2005-2015)

Panel A: Dependent variable: probability to receive a grant

\begin{tabular}{|c|c|c|c|c|c|c|}
\hline & (1) & $(2)$ & (3) & (4) & (5) & (6) \\
\hline Post & $\begin{array}{l}-0.081^{* * *} \\
(0.02)\end{array}$ & $\begin{array}{l}-0.123^{* * *} \\
(0.02)\end{array}$ & $\begin{array}{l}0.025 \\
(0.04)\end{array}$ & $\begin{array}{l}0.070^{*} \\
(0.04)\end{array}$ & $\begin{array}{l}0.001 \\
(0.04)\end{array}$ & $\begin{array}{l}-0.017 \\
(0.05)\end{array}$ \\
\hline MG & $\begin{array}{l}-0.150^{* * *} \\
(0.03)\end{array}$ & $\begin{array}{l}-0.019 \\
(0.03)\end{array}$ & $\begin{array}{l}-0.025 \\
(0.03)\end{array}$ & $\begin{array}{l}-0.125^{* * *} \\
(0.04)\end{array}$ & $\begin{array}{l}-0.035 \\
(0.03)\end{array}$ & $\begin{array}{l}-0.117^{* * *} \\
(0.04)\end{array}$ \\
\hline Post X MG & $\begin{array}{l}0.116^{* * *} \\
(0.03)\end{array}$ & $\begin{array}{l}0.110^{* * *} \\
(0.03)\end{array}$ & $\begin{array}{l}0.116^{* * * *} \\
(0.03)\end{array}$ & $\begin{array}{l}0.155^{* * *} \\
(0.03)\end{array}$ & $\begin{array}{l}0.127 * * * \\
(0.03)\end{array}$ & $\begin{array}{l}0.149 * * * \\
(0.03)\end{array}$ \\
\hline Constant & $\begin{array}{l}0.410^{* * *} \\
(0.01)\end{array}$ & $\begin{array}{l}0.283^{* * *} \\
(0.02)\end{array}$ & $\begin{array}{l}0.217 * * * \\
(0.03)\end{array}$ & $\begin{array}{l}0.319 * * * \\
(0.03)\end{array}$ & $\begin{array}{l}-1.112^{* * *} \\
(0.07)\end{array}$ & $\begin{array}{l}-1.400^{* * *} \\
(0.37)\end{array}$ \\
\hline $\mathrm{N}$ & 4318 & 4318 & 4318 & 4318 & 4267 & 4268 \\
\hline R-sq & 0.010 & 0.114 & 0.133 & 0.037 & 0.183 & 0.043 \\
\hline $\begin{array}{l}\text { Controls } \\
\text { Years }\end{array}$ & No & Yes & Yes & Yes & Yes & Yes \\
\hline Dummies & No & No & Yes & Yes & Yes & Yes \\
\hline Muni. F.E & No & No & No & Yes & No & Yes \\
\hline \multicolumn{7}{|c|}{ Panel B: Dependent variable: $\ln ($ Grant per capita) } \\
\hline & $(1)$ & $(2)$ & (3) & (4) & (5) & (6) \\
\hline Post & $\begin{array}{l}-0.389 * * * \\
(0.08)\end{array}$ & $\begin{array}{l}-0.290^{* * *} \\
(0.08)\end{array}$ & $\begin{array}{l}0.175 \\
(0.19)\end{array}$ & $\begin{array}{l}0.095 \\
(0.18)\end{array}$ & $\begin{array}{l}0.251 \\
(0.17)\end{array}$ & $\begin{array}{l}0.172 \\
(0.21)\end{array}$ \\
\hline MG & $\begin{array}{l}0.301^{* *} \\
(0.14)\end{array}$ & $\begin{array}{l}-0.156 \\
(0.14)\end{array}$ & $\begin{array}{l}-0.156 \\
(0.14)\end{array}$ & $\begin{array}{l}-0.352 \\
(0.23)\end{array}$ & $\begin{array}{l}-0.137 \\
(0.13)\end{array}$ & $\begin{array}{l}-0.368 \\
(0.23)\end{array}$ \\
\hline Post X MG & $\begin{array}{l}0.519 * * * \\
(0.17)\end{array}$ & $\begin{array}{l}0.626^{* * *} \\
(0.16)\end{array}$ & $\begin{array}{l}0.612^{* * *} \\
(0.16)\end{array}$ & $\begin{array}{l}0.414^{* *} \\
(0.17)\end{array}$ & $\begin{array}{l}0.582^{* * *} \\
(0.14)\end{array}$ & $\begin{array}{l}0.450^{* *} \\
(0.18)\end{array}$ \\
\hline Constant & $\begin{array}{l}4.944^{* * *} \\
(0.06)\end{array}$ & $\begin{array}{l}5.717 * * * \\
(0.09)\end{array}$ & $\begin{array}{l}5.452^{* * *} \\
(0.16)\end{array}$ & $\begin{array}{l}4.814^{* * *} \\
(0.17)\end{array}$ & $\begin{array}{l}10.081^{* * *} \\
(0.32)\end{array}$ & $\begin{array}{l}6.447^{* * * *} \\
(2.29)\end{array}$ \\
\hline $\mathrm{N}$ & 1440 & 1440 & 1440 & 1440 & 1440 & 1440 \\
\hline R-sq & 0.056 & 0.167 & 0.185 & 0.062 & 0.321 & 0.063 \\
\hline $\begin{array}{l}\text { Controls } \\
\text { Years }\end{array}$ & No & Yes & Yes & Yes & Yes & Yes \\
\hline Dummies & No & No & Yes & Yes & Yes & Yes \\
\hline Muni. F.E & No & No & No & Yes & No & Yes \\
\hline
\end{tabular}

Notes: Post $=1$ after the policy change and MG stands for municipalities group by either population size, geographic location or socioeconomic index. Control variables include the locality's ethnicity and its ranking in the different measures excluding the one interacted with the Post variable (either population size, geographic location or socioeconomic index). In columns 2-4, the control variables are binary (above and below the median) and in columns 5-6 they are continuous. * Indicates significance level of $10 \%$, ** indicates significance level of 5\%. *** Indicates significance level of $1 \%$. Clustered standard errors are in the parentheses in models 4 and 6.

Table 5: The effect of the policy change on grants, by ethnicity (Arab relative to Jewish localities, 1996-2001 versus 2005-2015)

Panel A: Dependent variable: probability to receive a grant

\begin{tabular}{lllllll}
\hline & $(1)$ & $(2)$ & $(3)$ & $(4)$ & $(5)$ & $(6)$ \\
\hline Post & $-0.078^{* * *}$ & $-0.103^{* * *}$ & 0.048 & $0.088^{* *}$ & 0.018 & -0.015 \\
& $(0.02)$ & $(0.02)$ & $(0.04)$ & $(0.04)$ & $(0.04)$ & $(0.05)$
\end{tabular}




\begin{tabular}{|c|c|c|c|c|c|c|}
\hline Arab & $\begin{array}{l}-0.216^{* * *} \\
(0.03)\end{array}$ & $\begin{array}{l}-0.190^{* * *} \\
(0.03)\end{array}$ & $\begin{array}{l}-0.192 * * * \\
(0.03)\end{array}$ & & $\begin{array}{l}-0.206^{* * *} \\
(0.03)\end{array}$ & \\
\hline Post*Arab & $\begin{array}{l}0.088^{* * * *} \\
(0.03)\end{array}$ & $\begin{array}{l}0.061^{* *} \\
(0.03)\end{array}$ & $\begin{array}{l}0.061^{* *} \\
(0.03)\end{array}$ & $\begin{array}{l}0.081^{* * * *} \\
(0.03)\end{array}$ & $\begin{array}{l}0.076^{* * *} \\
(0.03)\end{array}$ & $\begin{array}{l}0.078^{* *} \\
(0.03)\end{array}$ \\
\hline Constant & $\begin{array}{l}0.438 * * * \\
(0.01)\end{array}$ & $\begin{array}{l}0.336^{* * * *} \\
(0.02)\end{array}$ & $\begin{array}{l}0.270^{* * * *} \\
(0.03)\end{array}$ & $\begin{array}{l}0.301^{* * * *} \\
(0.03)\end{array}$ & $\begin{array}{l}-1.013^{* * * *} \\
(0.07)\end{array}$ & $\begin{array}{l}-1.732 * * * \\
(0.41)\end{array}$ \\
\hline $\begin{array}{l}\mathrm{N} \\
\mathrm{R}-\mathrm{sq} \\
\text { Controls }\end{array}$ & $\begin{array}{l}4318 \\
0.029 \\
\text { No } \\
\end{array}$ & $\begin{array}{l}4318 \\
0.116 \\
\text { Yes } \\
\end{array}$ & $\begin{array}{l}4318 \\
0.136 \\
\text { Yes } \\
\end{array}$ & $\begin{array}{l}4318 \\
0.034 \\
\text { Yes } \\
\end{array}$ & $\begin{array}{l}4249 \\
0.187 \\
\text { Yes } \\
\end{array}$ & $\begin{array}{l}4250 \\
0.040 \\
\text { Yes } \\
\end{array}$ \\
\hline \multicolumn{7}{|c|}{ Panel B: Dependent variable: $\ln ($ Grant per capita) } \\
\hline & (1) & $(2)$ & (3) & (4) & (5) & (6) \\
\hline Post & $\begin{array}{l}-0.278 * * * \\
(0.08)\end{array}$ & $\begin{array}{l}-0.193^{* *} \\
(0.08)\end{array}$ & $\begin{array}{l}0.250 \\
(0.19)\end{array}$ & $\begin{array}{l}0.118 \\
(0.18)\end{array}$ & $\begin{array}{l}0.347^{* *} \\
(0.17)\end{array}$ & $\begin{array}{l}0.160 \\
(0.21)\end{array}$ \\
\hline Arab & $\begin{array}{l}0.696^{* * * *} \\
(0.14)\end{array}$ & $\begin{array}{l}0.269 * \\
(0.14)\end{array}$ & $\begin{array}{l}0.299 * * \\
(0.14)\end{array}$ & & $\begin{array}{l}0.048 \\
(0.13)\end{array}$ & \\
\hline Post*Arab & $\begin{array}{l}0.185 \\
(0.17)\end{array}$ & $\begin{array}{l}0.301^{*} \\
(0.16)\end{array}$ & $\begin{array}{l}0.274^{*} \\
(0.16)\end{array}$ & $\begin{array}{l}0.107 \\
(0.16)\end{array}$ & $\begin{array}{l}0.146 \\
(0.15)\end{array}$ & $\begin{array}{l}0.192 \\
(0.17)\end{array}$ \\
\hline Constant & $\begin{array}{l}4.867^{* * * *} \\
(0.06)\end{array}$ & $\begin{array}{l}5.712^{* * *} \\
(0.10)\end{array}$ & $\begin{array}{l}5.449 * * * \\
(0.17)\end{array}$ & $\begin{array}{l}4.582^{* * *} \\
(0.17)\end{array}$ & $\begin{array}{l}10.174^{* * *} \\
(0.33)\end{array}$ & $\begin{array}{l}5.846^{* * *} \\
(2.52)\end{array}$ \\
\hline $\mathrm{N}$ & 1440 & 1440 & 1440 & 1440 & 1438 & 1438 \\
\hline R-sq & 0.070 & 0.157 & 0.176 & 0.059 & 0.315 & 0.059 \\
\hline $\begin{array}{l}\text { Controls } \\
\text { Year }\end{array}$ & No & Yes & Yes & Yes & Yes & Yes \\
\hline Dummies & No & No & Yes & Yes & Yes & Yes \\
\hline Muni. F.E & No & No & No & Yes & No & Yes \\
\hline
\end{tabular}

See notes to Table 4. 
Table 6: The effect of the policy change on grants, by geographic location

(localities in the bottom 1-3 to upper 4-10 deciles, ranked by periphery index, 1996-2001 versus 2005-2015)

Panel A: Dependent variable: probability to receive a grant

\begin{tabular}{lllllll}
\hline & $(1)$ & $(2)$ & $(3)$ & $(4)$ & $(5)$ & $(6)$ \\
\hline Post & $-0.054^{* * *}$ & $-0.089^{* * *}$ & 0.061 & $0.105^{* *}$ & 0.035 & -0.001 \\
& $(0.02)$ & $(0.02)$ & $(0.04)$ & $(0.04)$ & $(0.04)$ & $(0.05)$ \\
MG & $-0.123^{* * *}$ & -0.028 & -0.029 & & -0.013 & \\
& $(0.03)$ & $(0.03)$ & $(0.03)$ & & $(0.02)$ & \\
\multirow{2}{*}{ Post X MG } & 0.019 & 0.016 & 0.016 & 0.018 & 0.030 & 0.040 \\
& $(0.03)$ & $(0.03)$ & $(0.03)$ & $(0.03)$ & $(0.03)$ & $(0.03)$ \\
& & & & & & \\
Constant & $0.403^{* * *}$ & $0.356^{* * *}$ & $0.291^{* * *}$ & $0.277^{* * *}$ & $-1.008^{* * *}$ & $-1.721^{* * *}$ \\
& $(0.01)$ & $(0.02)$ & $(0.03)$ & $(0.03)$ & $(0.07)$ & $(0.40)$ \\
N & & & & & & \\
R-sq & 4318 & 4318 & 4318 & 4318 & 4250 & 4268 \\
Controls & 0.014 & 0.113 & 0.133 & 0.031 & 0.185 & 0.038 \\
\hline
\end{tabular}

Panel B: Dependent variable: $\ln ($ Grant per capita)

\begin{tabular}{|c|c|c|c|c|c|c|}
\hline & (1) & (2) & (3) & (4) & (5) & (6) \\
\hline Post & $\begin{array}{l}-0.138^{*} \\
(0.08)\end{array}$ & $\begin{array}{l}-0.086 \\
(0.08)\end{array}$ & $\begin{array}{l}0.364^{*} \\
(0.19)\end{array}$ & $\begin{array}{l}0.187 \\
(0.18)\end{array}$ & $\begin{array}{l}0.445^{* *} \\
(0.17)\end{array}$ & $\begin{array}{l}0.209 \\
(0.21)\end{array}$ \\
\hline MG & $\begin{array}{l}0.692^{* * *} \\
(0.13)\end{array}$ & $\begin{array}{l}0.251^{*} \\
(0.13)\end{array}$ & $\begin{array}{l}0.251^{*} \\
(0.13)\end{array}$ & & $\begin{array}{l}0.050 \\
(0.12)\end{array}$ & \\
\hline Post X MG & $\begin{array}{l}-0.320^{*} \\
(0.17)\end{array}$ & $\begin{array}{l}-0.209 \\
(0.16)\end{array}$ & $\begin{array}{l}-0.215 \\
(0.16)\end{array}$ & $\begin{array}{l}-0.205 \\
(0.16)\end{array}$ & $\begin{array}{l}-0.287^{* *} \\
(0.15)\end{array}$ & $\begin{array}{l}-0.192 \\
(0.16)\end{array}$ \\
\hline Constant & $\begin{array}{l}4.849 * * * \\
(0.06)\end{array}$ & $\begin{array}{l}5.479^{* * *} \\
(0.11)\end{array}$ & $\begin{array}{l}5.213^{* * * *} \\
(0.17)\end{array}$ & $\begin{array}{l}4.688^{* * *} \\
(0.17)\end{array}$ & $\begin{array}{l}10.407^{* * *} \\
(0.31)\end{array}$ & $\begin{array}{l}4.808^{* *} \\
(2.15)\end{array}$ \\
\hline $\mathrm{N}$ & 1440 & 1440 & 1440 & 1440 & 1438 & 1440 \\
\hline R-sq & 0.032 & 0.151 & 0.171 & 0.058 & 0.317 & 0.058 \\
\hline $\begin{array}{l}\text { Controls } \\
\text { Years }\end{array}$ & No & Yes & Yes & Yes & Yes & Yes \\
\hline Dummies & No & No & Yes & Yes & Yes & Yes \\
\hline Muni. F.E & No & No & No & Yes & No & Yes \\
\hline
\end{tabular}

See notes to Table 4 . 
Table 7: The effect of the policy change on grants, by population size

(localities in the bottom 1-3 to upper 4-10 deciles, ranked by population size), 1996-2001 versus 2005-2015)

Panel A: Dependent variable: probability to receive a grant

\begin{tabular}{lllllll}
\hline & $(1)$ & $(2)$ & $(3)$ & $(4)$ & $(5)$ & $(6)$ \\
\hline Post & $-0.064^{* * *}$ & $-0.059^{* * *}$ & $0.108^{* * *}$ & $0.107^{* * *}$ & $0.105^{* *}$ & $0.101^{* *}$ \\
& $(0.02)$ & $(0.02)$ & $(0.04)$ & $(0.04)$ & $(0.04)$ & $(0.04)$ \\
MG & $-0.287^{* * *}$ & $-0.253^{* * *}$ & $-0.253^{* * *}$ & & $-0.259^{* * *}$ & \\
& $(0.03)$ & $(0.03)$ & $(0.03)$ & & $(0.02)$ & \\
& & & & & & \\
Post X MG & 0.049 & 0.051 & $0.051^{*}$ & 0.050 & 0.047 & 0.046 \\
& $(0.03)$ & $(0.03)$ & $(0.03)$ & $(0.03)$ & $(0.03)$ & $(0.03)$ \\
& & & & & & \\
Constant & $0.454^{* * *}$ & $0.502^{* * *}$ & $0.428^{* * *}$ & $0.319^{* * *}$ & $0.440^{* * *}$ & $0.293^{* * *}$ \\
& $(0.01)$ & $(0.02)$ & $(0.03)$ & $(0.03)$ & $(0.03)$ & $(0.03)$ \\
N & & & & & & \\
R-sq & 4318 & 4318 & 4318 & 4318 & 4300 & 4293 \\
Controls & 0.065 & 0.093 & 0.115 & 0.032 & 0.114 & 0.032 \\
\hline
\end{tabular}

Panel B: Dependent variable: $\ln ($ Grant per capita)

\begin{tabular}{|c|c|c|c|c|c|c|}
\hline & (1) & (2) & (3) & (4) & (5) & (6) \\
\hline Post & $\begin{array}{l}-0.201^{\text {*** }} \\
(0.07)\end{array}$ & $\begin{array}{l}-0.213^{* * *} \\
(0.07)\end{array}$ & $\begin{array}{l}0.223 \\
(0.19)\end{array}$ & $\begin{array}{l}0.184 \\
(0.18)\end{array}$ & $\begin{array}{l}0.239 \\
(0.19)\end{array}$ & $\begin{array}{l}0.172 \\
(0.18)\end{array}$ \\
\hline MG & $\begin{array}{l}1.286^{* * *} \\
(0.16)\end{array}$ & $\begin{array}{l}1.171^{* * *} \\
(0.15)\end{array}$ & $\begin{array}{l}1.179 * * * \\
(0.15)\end{array}$ & & $\begin{array}{l}1.260^{* * * *} \\
(0.15)\end{array}$ & \\
\hline Post X MG & $\begin{array}{l}-0.147 \\
(0.20)\end{array}$ & $\begin{array}{l}-0.190 \\
(0.19)\end{array}$ & $\begin{array}{l}-0.164 \\
(0.19)\end{array}$ & $\begin{array}{l}-0.267 \\
(0.17)\end{array}$ & $\begin{array}{l}-0.191 \\
(0.19)\end{array}$ & $\begin{array}{l}-0.214 \\
(0.17)\end{array}$ \\
\hline Constant & $\begin{array}{l}4.830 * * * \\
(0.06)\end{array}$ & $\begin{array}{l}4.954^{* * *} \\
(0.09)\end{array}$ & $\begin{array}{l}4.645^{* * *} \\
(0.16)\end{array}$ & $\begin{array}{l}4.636^{* * *} \\
(0.14)\end{array}$ & $\begin{array}{l}4.431^{* * *} \\
(0.15)\end{array}$ & $\begin{array}{l}4.787^{* * * *} \\
(0.12)\end{array}$ \\
\hline $\mathrm{N}$ & 1440 & 1440 & 1440 & 1440 & 1438 & 1438 \\
\hline R-sq & 0.102 & 0.158 & 0.180 & 0.060 & 0.180 & 0.059 \\
\hline Controls & No & Yes & Yes & Yes & Yes & Yes \\
\hline Years Dummies & No & No & Yes & Yes & Yes & Yes \\
\hline Muni. F.E & No & No & No & Yes & No & Yes \\
\hline
\end{tabular}

See notes to Table 4. 
Table 8: The effect of the policy change on the probability to get grants, by socioeconomic rank (panel A) and ethnicity (panel B), 1996-2001 versus 2002/2003/2004-2015

\begin{tabular}{|c|c|c|c|c|c|c|}
\hline & (1) & $\begin{array}{l}(2) \\
1996-2\end{array}$ & $\begin{array}{c}(3) \\
\text { versus } 2\end{array}$ & $\begin{array}{c}(4) \\
2015\end{array}$ & (5) & (6) \\
\hline \multicolumn{7}{|c|}{ by socioeconomic rank } \\
\hline Post X SEI Bottom3 & $\begin{array}{l}0.109 * * * \\
(0.03)\end{array}$ & $\begin{array}{l}0.099 * * * \\
(0.03)\end{array}$ & $\begin{array}{l}0.106^{* * *} \\
(0.03)\end{array}$ & $\begin{array}{l}0.139 * * * \\
(0.03)\end{array}$ & $\begin{array}{l}0.118^{* * *} \\
(0.03)\end{array}$ & $\begin{array}{l}0.133^{* * *} \\
(0.03)\end{array}$ \\
\hline Constant & $\begin{array}{l}0.410^{* * *} \\
(0.01)\end{array}$ & $\begin{array}{l}0.279 * * * \\
(0.02)\end{array}$ & $\begin{array}{l}0.212^{* * *} \\
(0.03)\end{array}$ & $\begin{array}{l}0.321^{* * *} \\
(0.03)\end{array}$ & $\begin{array}{l}-1.075^{* * *} \\
(0.06)\end{array}$ & $\begin{array}{l}-1.320^{* * *} \\
(0.34)\end{array}$ \\
\hline $\begin{array}{l}\mathrm{N} \\
\mathrm{R}-\mathrm{sq}\end{array}$ & $\begin{array}{l}5080 \\
0.009 \\
\end{array}$ & $\begin{array}{l}5080 \\
0.104 \\
\end{array}$ & $\begin{array}{l}5080 \\
0.125 \\
\end{array}$ & $\begin{array}{l}5080 \\
0.033 \\
\end{array}$ & $\begin{array}{l}5020 \\
0.171 \\
\end{array}$ & $\begin{array}{l}5021 \\
0.038 \\
\end{array}$ \\
\hline \multicolumn{7}{|c|}{ by ethnicity } \\
\hline Post X Arab & $\begin{array}{l}0.096^{* * *} \\
(0.03)\end{array}$ & $\begin{array}{l}0.073 * * \\
(0.03)\end{array}$ & $\begin{array}{l}0.073 * * \\
(0.03)\end{array}$ & $\begin{array}{l}0.094^{* * *} \\
(0.03)\end{array}$ & $\begin{array}{l}0.086^{* * * *} \\
(0.03)\end{array}$ & $\begin{array}{l}0.095^{* * *} \\
(0.03)\end{array}$ \\
\hline Constant & $\begin{array}{l}0.438^{* * *} \\
(0.01)\end{array}$ & $\begin{array}{l}0.334 * * * \\
(0.02)\end{array}$ & $\begin{array}{l}0.264 * * * \\
(0.03)\end{array}$ & $\begin{array}{l}0.282^{* * *} \\
(0.03)\end{array}$ & $\begin{array}{l}-0.977 * * * \\
(0.07)\end{array}$ & $\begin{array}{l}-1.558 * * * \\
(0.37)\end{array}$ \\
\hline $\begin{array}{l}\mathrm{N} \\
\mathrm{R}-\mathrm{sq}\end{array}$ & $\begin{array}{l}5080 \\
0.025 \\
\end{array}$ & $\begin{array}{l}5080 \\
0.108 \\
\end{array}$ & $\begin{array}{l}5080 \\
0.129 \\
\end{array}$ & $\begin{array}{l}5080 \\
0.031 \\
\end{array}$ & $\begin{array}{l}5002 \\
0.175 \\
\end{array}$ & $\begin{array}{l}5003 \\
0.036 \\
\end{array}$ \\
\hline \multicolumn{7}{|c|}{ 1996-2001 versus 2003-2015 } \\
\hline \multicolumn{7}{|c|}{ by socioeconomic rank } \\
\hline Post X SEI Bottom3 & $\begin{array}{l}0.120^{* * *} \\
(0.03)\end{array}$ & $\begin{array}{l}0.110 * * * \\
(0.03)\end{array}$ & $\begin{array}{l}0.117 * * * \\
(0.03)\end{array}$ & $\begin{array}{l}0.153^{* * *} \\
(0.03)\end{array}$ & $\begin{array}{l}0.128^{* * * *} \\
(0.03)\end{array}$ & $\begin{array}{l}0.147^{* * * *} \\
(0.03)\end{array}$ \\
\hline Constant & $\begin{array}{l}0.410^{* * *} \\
(0.01)\end{array}$ & $\begin{array}{l}0.280^{* * *} \\
(0.02)\end{array}$ & $\begin{array}{l}0.213^{* * *} \\
(0.03)\end{array}$ & $\begin{array}{l}0.324^{* * *} \\
(0.03)\end{array}$ & $\begin{array}{l}-1.077 * * * \\
(0.06)\end{array}$ & $\begin{array}{l}-1.251^{* * *} \\
(0.34)\end{array}$ \\
\hline $\begin{array}{l}\mathrm{N} \\
\mathrm{R}-\mathrm{sq}\end{array}$ & $\begin{array}{l}4826 \\
0.009 \\
\end{array}$ & $\begin{array}{l}4826 \\
0.107 \\
\end{array}$ & $\begin{array}{l}4826 \\
0.127 \\
\end{array}$ & $\begin{array}{l}4826 \\
0.035 \\
\end{array}$ & $\begin{array}{l}4767 \\
0.173 \\
\end{array}$ & $\begin{array}{l}4768 \\
0.039 \\
\end{array}$ \\
\hline \multicolumn{7}{|c|}{ by ethnicity } \\
\hline Post X Arab & $\begin{array}{l}0.100^{* * *} \\
(0.03)\end{array}$ & $\begin{array}{l}0.075 * * \\
(0.03)\end{array}$ & $\begin{array}{l}0.075 * * * \\
(0.03)\end{array}$ & $\begin{array}{l}0.096^{* * *} \\
(0.03)\end{array}$ & $\begin{array}{l}0.088^{* * * *} \\
(0.03)\end{array}$ & $\begin{array}{l}0.096^{* * * *} \\
(0.03)\end{array}$ \\
\hline Constant & $\begin{array}{l}0.438 * * * \\
(0.01)\end{array}$ & $\begin{array}{l}0.336 * * * \\
(0.02)\end{array}$ & $\begin{array}{l}0.268^{* * *} \\
(0.03)\end{array}$ & $\begin{array}{l}0.287 * * * \\
(0.03)\end{array}$ & $\begin{array}{l}-0.973^{* * *} \\
(0.07)\end{array}$ & $\begin{array}{l}-1.534^{* * *} \\
(0.38)\end{array}$ \\
\hline $\mathrm{N}$ & 4826 & 4826 & 4826 & 4826 & 4749 & 4750 \\
\hline \multicolumn{7}{|c|}{ 1996-2001 versus 2004-2015 } \\
\hline \multicolumn{7}{|c|}{ by socioeconomic rank } \\
\hline Post X SEI Bottom3 & $\begin{array}{l}0.129 * * * \\
(0.03)\end{array}$ & $\begin{array}{l}0.121^{* * *} \\
(0.03)\end{array}$ & $\begin{array}{l}0.127 * * * \\
(0.03)\end{array}$ & $\begin{array}{l}0.167^{* * *} \\
(0.03)\end{array}$ & $\begin{array}{l}0.138^{* * * *} \\
(0.03)\end{array}$ & $\begin{array}{l}0.160^{* * *} \\
(0.03)\end{array}$ \\
\hline Constant & $\begin{array}{l}0.410^{* * *} \\
(0.01)\end{array}$ & $\begin{array}{l}0.283^{* * *} \\
(0.02)\end{array}$ & $\begin{array}{l}0.217^{* * *} \\
(0.03)\end{array}$ & $\begin{array}{l}0.323^{* * * *} \\
(0.03)\end{array}$ & $\begin{array}{l}-1.097 * * * \\
(0.07)\end{array}$ & $\begin{array}{l}-1.298 * * * \\
(0.35)\end{array}$ \\
\hline $\mathrm{N}$ & 4572 & 4572 & 4572 & 4572 & 4514 & 4515 \\
\hline R-sq & 0.010 & 0.110 & 0.129 & 0.037 & 0.178 & 0.042 \\
\hline \multicolumn{7}{|c|}{ by ethnicity } \\
\hline Post X Arab & $\begin{array}{l}0.102^{* * *} \\
(0.03)\end{array}$ & $\begin{array}{l}0.075 * * \\
(0.03)\end{array}$ & $\begin{array}{l}0.075 * * \\
(0.03)\end{array}$ & $\begin{array}{l}0.096^{* * * *} \\
(0.03)\end{array}$ & $\begin{array}{l}0.089 * * * \\
(0.03)\end{array}$ & $\begin{array}{l}0.092^{* * * *} \\
(0.03)\end{array}$ \\
\hline Constant & $\begin{array}{l}0.438^{* * *} \\
(0.01)\end{array}$ & $\begin{array}{l}0.341^{* * *} \\
(0.02)\end{array}$ & $\begin{array}{l}0.275^{* * *} \\
(0.03)\end{array}$ & $\begin{array}{l}0.298 * * * \\
(0.03)\end{array}$ & $\begin{array}{l}-0.993^{* * *} \\
(0.07)\end{array}$ & $\begin{array}{l}-1.622^{* * *} \\
(0.39)\end{array}$ \\
\hline $\mathrm{N}$ & 4572 & 4572 & 4572 & 4572 & 4496 & 4497 \\
\hline R-sq & 0.027 & 0.113 & 0.132 & 0.033 & 0.182 & 0.039 \\
\hline Controls & No & Yes & Yes & Yes & Yes & Yes \\
\hline Years Dummies & No & No & Yes & Yes & Yes & Yes \\
\hline Muni. F.E & No & No & No & Yes & No & Yes \\
\hline
\end{tabular}

See notes to Table 4 . The main effects are presented in the table for space reasons. 
Table 9: The effect of the policy change on grants, by socioeconomic rank (localities in the bottom $\mathrm{i}$ to upper (i+1)-10 deciles, ranked by socioeconomic index), 1996-2001 versus 2005-2015)

Panel A: Dependent variable: probability to receive a grant

\begin{tabular}{llllll}
\hline & $\begin{array}{l}\text { Bottom } \\
\text { decile }\end{array}$ & $\begin{array}{l}\text { Bottom } \\
\text { 2 deciles }\end{array}$ & $\begin{array}{l}\text { Bottom } \\
\text { 3 deciles }\end{array}$ & $\begin{array}{l}\text { Bottom } \\
\text { 4 deciles }\end{array}$ & $\begin{array}{l}\text { Bottom } \\
5 \text { deciles }\end{array}$ \\
\hline \multirow{2}{*}{ Post } & & & & & \\
& 0.010 & -0.003 & -0.017 & -0.024 & -0.038 \\
& $(0.04)$ & $(0.04)$ & $(0.05)$ & $(0.05)$ & $(0.05)$ \\
Bottom $i$ & & & & & \\
& -0.075 & $-0.106^{* *}$ & $-0.117^{* * *}$ & $-0.086^{* *}$ & -0.009 \\
& $(0.06)$ & $(0.04)$ & $(0.04)$ & $(0.04)$ & $(0.04)$ \\
Post X Bottom $i$ & & & & & \\
& $0.196^{* * *}$ & $0.170^{* * *}$ & $0.149^{* * *}$ & $0.113^{* * *}$ & $0.113^{* * *}$ \\
& $(0.05)$ & $(0.04)$ & $(0.03)$ & $(0.03)$ & $(0.03)$ \\
N & & & & & \\
R-sq & 4268 & 4268 & 4268 & 4268 & 4268 \\
Controls & 0.0418 & 0.0426 & 0.0432 & 0.0414 & 0.0422 \\
Muni. F.E & Yes & Yes & Yes & Yes & Yes \\
Year Dummies & Yes & Yes & Yes & Yes & Yes \\
\hline
\end{tabular}

Panel B: Dependent variable: $\ln ($ Grant per capita)

\begin{tabular}{llllll}
\hline & $\begin{array}{l}\text { Bottom } \\
\text { decile }\end{array}$ & $\begin{array}{l}\text { Bottom } \\
\text { 2 deciles }\end{array}$ & $\begin{array}{l}\text { Bottom } \\
\text { 3 deciles }\end{array}$ & $\begin{array}{l}\text { Bottom } \\
\text { 4 deciles }\end{array}$ & $\begin{array}{l}\text { Bottom } \\
5 \text { deciles }\end{array}$ \\
\hline Post & & & & & \\
& 0.216 & 0.186 & 0.172 & 0.120 & 0.086 \\
& $(0.21)$ & $(0.21)$ & $(0.21)$ & $(0.21)$ & $(0.21)$ \\
Bottom $i$ & -0.319 & -0.075 & -0.368 & $-0.301^{*}$ & $-0.357^{* *}$ \\
& $(0.28)$ & $(0.25)$ & $(0.23)$ & $(0.18)$ & $(0.15)$ \\
Post X Bottom $i$ & $0.527^{* *}$ & 0.308 & $0.450^{* *}$ & $0.330^{* *}$ & $0.229^{*}$ \\
& $(0.25)$ & $(0.19)$ & $(0.18)$ & $(0.15)$ & $(0.13)$ \\
& & & & & \\
N & 1440 & 1440 & 1440 & 1440 & 1440 \\
R-sq & 0.0597 & 0.0588 & 0.0629 & 0.0612 & 0.0608 \\
Controls & Yes & Yes & Yes & Yes & Yes \\
Muni. F.E & Yes & Yes & Yes & Yes & Yes \\
Year Dummies & Yes & Yes & Yes & Yes & Yes \\
\hline See notes to Tabes
\end{tabular}

See notes to Table 4 (model 6). 
Table 10a: The effect of the policy change on grants, by socioeconomic rank (full period) (localities in the bottom 1-3 to upper 4-10 deciles, ranked by socioeconomic index, 1990-2001 versus 2005-2015)

Panel A: Dependent variable: probability to receive a grant

\begin{tabular}{lllllll}
\hline & $(1)$ & $(2)$ & $(3)$ & $(4)$ & $(5)$ & $(6)$ \\
\hline Post & $0.038^{* * *}$ & -0.009 & $0.264^{* * *}$ & $0.311^{* * *}$ & $0.236^{* * *}$ & $0.224^{* * *}$ \\
& $(0.01)$ & $(0.01)$ & $(0.04)$ & $(0.04)$ & $(0.04)$ & $(0.04)$ \\
& & & & & & \\
& $-0.101^{* * *}$ & 0.017 & 0.004 & $-0.057^{* *}$ & -0.011 & $-0.069^{* *}$ \\
& $(0.02)$ & $(0.02)$ & $(0.02)$ & $(0.03)$ & $(0.02)$ & $(0.03)$ \\
Post X MG & & & & & & \\
& $0.067^{* * *}$ & $0.063^{* *}$ & $0.074^{* * *}$ & $0.110^{* * *}$ & $0.096^{* * *}$ & $0.109^{* * *}$ \\
& $(0.03)$ & $(0.02)$ & $(0.02)$ & $(0.03)$ & $(0.02)$ & $(0.03)$ \\
Constant & & & & & & \\
& $0.290^{* * *}$ & $0.181^{* * *}$ & -0.003 & $0.057^{* * *}$ & $-1.103^{* * *}$ & $-1.206^{* * *}$ \\
& $(0.01)$ & $(0.01)$ & $(0.03)$ & $(0.02)$ & $(0.06)$ & $(0.22)$ \\
N & & & & & & \\
R-sq & 5842 & 5842 & 5842 & 5842 & 5666 & 5670 \\
Controls & 0.009 & 0.102 & 0.146 & 0.069 & 0.179 & 0.070 \\
Years Dummies & No & Yes & Yes & Yes & Yes & Yes \\
Muni. F.E & No & No & Yes & Yes & Yes & Yes \\
\hline
\end{tabular}

Panel B: Dependent variable: $\ln ($ Grant per capita)

\begin{tabular}{lllllll}
\hline & $(1)$ & $(2)$ & $(3)$ & $(4)$ & $(5)$ & $(6)$ \\
\hline Post & $-0.250^{* * *}$ & $-0.125^{*}$ & $0.587^{*}$ & 0.328 & $0.564^{*}$ & 0.488 \\
& $(0.07)$ & $(0.07)$ & $(0.35)$ & $(0.31)$ & $(0.32)$ & $(0.34)$ \\
MG & $0.500^{* * *}$ & 0.015 & 0.010 & -0.179 & -0.012 & -0.185 \\
& $(0.12)$ & $(0.12)$ & $(0.12)$ & $(0.16)$ & $(0.11)$ & $(0.17)$ \\
Post X MG & & & & & & \\
& $0.321^{* *}$ & $0.428^{* * *}$ & $0.433^{* * *}$ & 0.240 & $0.425^{* * *}$ & $0.270^{*}$ \\
& $(0.15)$ & $(0.14)$ & $(0.14)$ & $(0.16)$ & $(0.13)$ & $(0.16)$ \\
Constant & & & & & & \\
& $4.806^{* * *}$ & $5.627^{* * *}$ & $5.124^{* * *}$ & $4.639^{* * *}$ & $10.177^{* * *}$ & $7.195^{* * *}$ \\
& $(0.05)$ & $(0.08)$ & $(0.33)$ & $(0.30)$ & $(0.39)$ & $(1.61)$ \\
N & & & & & & \\
R-sq & 1680 & 1680 & 1680 & 1680 & 1680 & 1680 \\
Controls & 0.051 & 0.184 & 0.210 & 0.060 & 0.353 & 0.062 \\
Years Dummies & No & Yes & Yes & Yes & Yes & Yes \\
Muni. F.E & No & No & Yes & Yes & Yes & Yes \\
\hline
\end{tabular}

See notes to Table 4. 
Table 10b: The effect of the policy change on grants, by ethnicity (full period)

(Arab relative to Jewish localities, 1990-2001 versus 2005-2015)

Panel A: Dependent variable: probability to receive a grant

\begin{tabular}{|c|c|c|c|c|c|c|}
\hline & (1) & (2) & (3) & (4) & (5) & (6) \\
\hline Post & $\begin{array}{l}0.041^{* * *} \\
(0.01)\end{array}$ & $\begin{array}{l}0.008 \\
(0.01)\end{array}$ & $\begin{array}{l}0.287 * * * \\
(0.04)\end{array}$ & $\begin{array}{l}0.331^{* * *} \\
(0.04)\end{array}$ & $\begin{array}{l}0.260 * * * \\
(0.04)\end{array}$ & $\begin{array}{l}0.239 * * * \\
(0.04)\end{array}$ \\
\hline Arab & $\begin{array}{l}-0.172^{* * *} \\
(0.02)\end{array}$ & $\begin{array}{l}-0.122^{* * *} \\
(0.02)\end{array}$ & $\begin{array}{l}-0.132^{* * *} \\
(0.02)\end{array}$ & & $\begin{array}{l}-0.164^{* * *} \\
(0.02)\end{array}$ & \\
\hline Arab X Post & $\begin{array}{l}0.044^{*} \\
(0.02)\end{array}$ & $\begin{array}{l}0.022 \\
(0.02)\end{array}$ & $\begin{array}{l}0.021 \\
(0.02)\end{array}$ & $\begin{array}{l}0.037 \\
(0.03)\end{array}$ & $\begin{array}{l}0.040^{*} \\
(0.02)\end{array}$ & $\begin{array}{l}0.046^{*} \\
(0.03)\end{array}$ \\
\hline Constant & $\begin{array}{l}0.320 * * * \\
(0.01)\end{array}$ & $\begin{array}{l}0.206^{* * *} \\
(0.02)\end{array}$ & $\begin{array}{l}0.025 \\
(0.03)\end{array}$ & $\begin{array}{l}0.051^{* *} \\
(0.02)\end{array}$ & $\begin{array}{l}-1.035^{* * *} \\
(0.06)\end{array}$ & $\begin{array}{l}-1.290 * * * \\
(0.24)\end{array}$ \\
\hline $\mathrm{N}$ & 5842 & 5842 & 5842 & 5842 & 5624 & 5628 \\
\hline R-sq & 0.029 & 0.102 & 0.146 & 0.066 & 0.180 & 0.068 \\
\hline Controls & No & Yes & Yes & Yes & Yes & Yes \\
\hline Year Dummies & No & No & Yes & Yes & Yes & Yes \\
\hline Muni. F.E & No & No & No & Yes & No & Yes \\
\hline
\end{tabular}

Panel B: Dependent variable: $\ln ($ Grant per capita)

\begin{tabular}{lllllll}
\hline & $(1)$ & $(2)$ & $(3)$ & $(4)$ & $(5)$ & $(6)$ \\
\hline Post & $-0.166^{* *}$ & -0.042 & $0.652^{*}$ & 0.292 & $0.630^{* *}$ & 0.423 \\
& $(0.07)$ & $(0.07)$ & $(0.35)$ & $(0.31)$ & $(0.32)$ & $(0.34)$ \\
Arab & $0.816^{* * *}$ & $0.392^{* * *}$ & $0.380^{* * *}$ & & & \\
& $(0.12)$ & $(0.13)$ & $(0.13)$ & & 0.167 & \\
& & & & & $(0.11)$ & \\
Arab X Post & 0.065 & 0.161 & 0.169 & 0.008 & 0.042 & 0.069 \\
& $(0.16)$ & $(0.15)$ & $(0.15)$ & $(0.14)$ & $(0.14)$ & $(0.15)$ \\
Constant & $4.755^{* * *}$ & $5.653^{* * *}$ & $5.156^{* * *}$ & $4.497^{* * *}$ & $10.282^{* * *}$ & $7.022^{* * *}$ \\
& $(0.05)$ & $(0.09)$ & $(0.34)$ & $(0.29)$ & $(0.40)$ & $(1.75)$ \\
N & & & & & & \\
R-sq & 1680 & 1680 & 1680 & 1680 & 1678 & 1678 \\
Controls & 0.067 & 0.178 & 0.204 & 0.061 & 0.348 & 0.062 \\
Year Dummies & No & Yes & Yes & Yes & Yes & Yes \\
Muni. F.E & No & No & Yes & Yes & Yes & Yes \\
\hline
\end{tabular}

See notes to Table 4. 
Table 11: The effect of the policy change on the probability to get grants, by socioeconomic rank (panel A) and ethnicity (panel B) and by investigated period ( $y$-2001 versus 2005-2015

\begin{tabular}{|c|c|c|c|c|c|c|}
\hline starting year $y$ & 1990 & 1991 & 1992 & 1993 & 1994 & 1995 \\
\hline Post & $\begin{array}{l}0.224^{* * *} \\
(0.04)\end{array}$ & $\begin{array}{l}0.158 * * * \\
(0.04)\end{array}$ & $\begin{array}{l}0.138^{* * *} \\
(0.04)\end{array}$ & $\begin{array}{l}0.049 \\
(0.04)\end{array}$ & $\begin{array}{l}0.071 \\
(0.05)\end{array}$ & $\begin{array}{l}0.090^{*} \\
(0.05)\end{array}$ \\
\hline MG & $\begin{array}{l}-0.069^{* *} \\
(0.03)\end{array}$ & $\begin{array}{l}-0.072 * * * \\
(0.03)\end{array}$ & $\begin{array}{l}-0.078^{* * *} \\
(0.03)\end{array}$ & $\begin{array}{l}-0.078^{* *} \\
(0.03)\end{array}$ & $\begin{array}{l}-0.091^{* * *} \\
(0.03)\end{array}$ & $\begin{array}{l}-0.103^{* * *} \\
(0.03)\end{array}$ \\
\hline Post X MG & $\begin{array}{l}0.109 * * * \\
(0.03)\end{array}$ & $\begin{array}{l}0.114^{* * * *} \\
(0.03)\end{array}$ & $\begin{array}{l}0.121^{* * *} \\
(0.03)\end{array}$ & $\begin{array}{l}0.125^{* * * *} \\
(0.03)\end{array}$ & $\begin{array}{l}0.131^{* * *} \\
(0.03)\end{array}$ & $\begin{array}{l}0.134^{* * * *} \\
(0.03)\end{array}$ \\
\hline Constant & $\begin{array}{l}-1.206^{* * *} \\
(0.22)\end{array}$ & $\begin{array}{l}-1.216^{* * * *} \\
(0.24)\end{array}$ & $\begin{array}{l}-1.162^{* * *} \\
(0.26)\end{array}$ & $\begin{array}{l}-1.052^{* * *} \\
(0.27)\end{array}$ & $\begin{array}{l}-1.128^{* * *} \\
(0.29)\end{array}$ & $\begin{array}{l}-1.212^{* * *} \\
(0.38)\end{array}$ \\
\hline $\begin{array}{l}\mathrm{N} \\
\mathrm{R} \text {-sq } \\
\text { Controls } \\
\text { Years Dummies } \\
\text { Muni. F.E }\end{array}$ & $\begin{array}{l}5670 \\
0.070 \\
\text { Yes } \\
\text { Yes } \\
\text { Yes }\end{array}$ & $\begin{array}{l}5442 \\
0.058 \\
\text { Yes } \\
\text { Yes } \\
\text { Yes }\end{array}$ & $\begin{array}{l}5212 \\
0.051 \\
\text { Yes } \\
\text { Yes } \\
\text { Yes }\end{array}$ & $\begin{array}{l}4977 \\
0.045 \\
\text { Yes } \\
\text { Yes } \\
\text { Yes }\end{array}$ & $\begin{array}{l}4741 \\
0.046 \\
\text { Yes } \\
\text { Yes } \\
\text { Yes }\end{array}$ & $\begin{array}{l}4504 \\
0.044 \\
\text { Yes } \\
\text { Yes } \\
\text { Yes }\end{array}$ \\
\hline \multicolumn{7}{|c|}{ Panel B: By ethnicity } \\
\hline starting year $y$ & $\begin{array}{l}1990 \\
(6) \\
\end{array}$ & $\begin{array}{l}1991 \\
(6)\end{array}$ & $\begin{array}{l}1992 \\
(6)\end{array}$ & $\begin{array}{l}1993 \\
(6)\end{array}$ & $\begin{array}{l}1994 \\
(6)\end{array}$ & $\begin{array}{l}1995 \\
(6)\end{array}$ \\
\hline Post & $\begin{array}{l}0.239 * * * \\
(0.04)\end{array}$ & $\begin{array}{l}0.169 * * * \\
(0.04)\end{array}$ & $\begin{array}{l}0.148^{* * * *} \\
(0.04)\end{array}$ & $\begin{array}{l}0.055 \\
(0.05)\end{array}$ & $\begin{array}{l}0.075 \\
(0.05)\end{array}$ & $\begin{array}{l}0.094^{* *} \\
(0.05)\end{array}$ \\
\hline Arab X Post & $\begin{array}{l}0.046^{*} \\
(0.03)\end{array}$ & $\begin{array}{l}0.054^{* *} \\
(0.03)\end{array}$ & $\begin{array}{l}0.059 * * \\
(0.03)\end{array}$ & $\begin{array}{l}0.067^{* *} \\
(0.03)\end{array}$ & $\begin{array}{l}0.074^{* * * *} \\
(0.03)\end{array}$ & $\begin{array}{l}0.073 * * \\
(0.03)\end{array}$ \\
\hline Constant & $\begin{array}{l}-1.290^{* * *} \\
(0.24)\end{array}$ & $\begin{array}{l}-1.320^{* * *} \\
(0.26)\end{array}$ & $\begin{array}{l}-1.285^{* * *} \\
(0.28)\end{array}$ & $\begin{array}{l}-1.196^{* * *} \\
(0.29)\end{array}$ & $\begin{array}{l}-1.298^{* * *} \\
(0.31)\end{array}$ & $\begin{array}{l}-1.442^{* * *} \\
(0.39)\end{array}$ \\
\hline $\mathrm{N}$ & 5628 & 5404 & 5178 & 4947 & 4715 & 4482 \\
\hline R-sq & 0.068 & 0.056 & 0.049 & 0.043 & 0.043 & 0.041 \\
\hline Controls & Yes & Yes & Yes & Yes & Yes & Yes \\
\hline Year Dummies & Yes & Yes & Yes & Yes & Yes & Yes \\
\hline Muni. F.E & Yes & Yes & Yes & Yes & Yes & Yes \\
\hline
\end{tabular}

See notes to Table 4 (model 6). 